\title{
IDENTIFIKASI POTENSI WISATA KULINER BERBASIS BAHAN BAKU LOKAL DI KABUPATEN BULELENG, BALI
}

\author{
I Ketut Margi ${ }^{1}$ Risa Panti Ariani ${ }^{2}$ Ni Made Ary Widiastini ${ }^{3}$ Ni Made Suriani ${ }^{4}$ \\ 1Jurusan Pendidikan Sejarah, Fakultas IImu Sosial, ${ }^{2,4}$ Jurusan Pendidikan Kesejahteraan \\ Keluarga, ${ }^{3}$ Jurusan Perhotelan, Universitas Pendidikan Ganesha, \\ Singaraja, Indonesia
}

e-mail: ketutmargi@yahoo.co.id,rp_ariani@yahoo.co.id, ary.widiastini@gmail.com,

\begin{abstract}
Abstrak
Penelitian ini bertujuan untuk mengidentifikasi potensi wisata kuliner yang dapat dikembangkan di Kabupaten Buleleng. Metode penelitian ini adalah studi dokumentasi, observasi lapangan dan wawancara mendalam, sedangkan analisis yang digunakan adalah analisis deskriptif kualitatif. Temuan di lapangan menunjukkan hasil produksi unggulan masyarakat yang dapat dimanfaatkan menjadi produk wisata kuliner ada tiga jenis yakni buah duren, singkong/ubi jalar/ubi ungu, dan buah anggur. Ketiga hasil produksi unggulan ini dapat diolah menjadi berbagai jenis makanan dan minuman yang telah diuji kualitas baik dari segi rasa, bentuk, maupun tekstur. Melalui uji kualitas dengan melibatkan pakar kuliner dari perwakilan hotel, restoran, dan akademisi dihasilkan beberapa resep, yakni: kolak duren, dodol duren, jus duren spesial, pudding duren kane, dodol ubi jalar, pound cake ubi jalar ungu, opak kulit singkong, singkong rebus tuak, jus anggur, pudding anggur, dan agaragar anggur. Berdasarkan kenyataan tersebut di Kabupaten Buleleng berpotensi dikembangkan wisata alternatif, yakni wisata kuliner. Hal ini penting karena bukan sematamata berkembangnya diversifikasi produk wisata, akan tetapi sekaligus menumbuhkan ekonomi kreatif di kalangan anggota masyarakat. Untuk mewujudkannya perlu adanya perhatian khusus serta sinergisitas pihak pemerintah daerah, pengusaha pariwisata, dan masyarakat (petani).
\end{abstract}

\begin{abstract}
This study aimed to identification the natural resources from agriculture that potential to develop to be a culinary tourism in Buleleng regency. Study of documentation, field observations and in-depth interviews are used as a method in this research, and analyzed by a qualitative descriptive analysis. There are three an excellent product that can be processed into a culinary products such as durian, cassava/sweet potato/purple potato and grapes. The third of an excellent product can be processed into a variety of foods and beverages that have been a good taste, a nice shape and a good texture of the culinary product. Through the quality test involving the experts: hotel practice, restaurant practice and the education, finally founded some qualified recipes are: a compote durian, dodol durian, special juice of durian, pudding from durian kane, sweet potato dodol, pound cake from purple sweet potato, chips from skin cassava, boiled cassava by tuak, grape juice, grape pudding and grape jelly. Based on this fact in Buleleng regency potentially developed alternative tourism, which is a culinary tour. This is important because not only the development of diversified tourism products, but at the same time grow the creative economy among members of society. To realize the need for special attention as well as the synergy of local government, tourism entrepreneurs, and communities (farmers).
\end{abstract}

Key words: tourism, culinary, agriculture resources. 


\section{PENDAHULUAN}

Seni kuliner merupakan salah satu daya tarik bagi wisatawan mancanegara yang mengadakan suatu perjalanan wisata dengan tujuan untuk menikmati berbagai jenis makanan yang enak. Dalam mengemas masakan menjadi produk wisata tentu harus memperhatikan standar-standar, baik pada teknik pengolahan, rasa, maupun teknik penyajiannya. Pada penelitian ini, hasil produksi pertanian, peternakan dan perikanan yang dikembangkan menjadi produk wisata kuliner juga harus mengikuti standar-standar tersebut sehingga hasil olahan dapat diterima oleh konsumen terutama wisatawan. Oleh karena itu, pendapat Ariani $(1994 ; 2011)$ yang mengemukakan bahwa seni kuliner harus terus digali dan dikembangkan mengingat Indonesia, khususnya Bali memiliki berbagai hasil produksi yang dapat diolah menjadi berbagai jenis makanan dan minuman patut diperhatikan. Hal ini selain dapat mempertahankan hasil produksi, melestarikan budaya Bali, khususnya masakan tradisional Bali juga dapat menjadi usaha yang memberikan masukan berupa penghasilan bagi masyarakat dan daerah di Bali.

Di Bali, saat ini banyak sekali dikembangkan tempat makan di antaranya kafe, restoran, resto yang menyajikan berbagai jenis makanan dan minuman ala Indonesia, Cina, dan Eropa. Bahkan, pedagang-pedagang furniture yang ada di daerah Gianyar banyak yang menggeser fungsinya menjadi tempat makan istimewa dengan harga yang tidak terlalu mahal akibat dari menurunnya minat wisatawan terhadap furniture tersebut. Melihat hal tersebut, dapat dikatakan bahwa minat wisatawan terhadap wisata kuliner cukup tinggi. Hanya dengan melakukan kerja sama yang baik terhadap pihak biro perjalanan wisata, maka wisatawan pun akan datang dalam jumlah yang cukup banyak ke tempat makan tersebut.
Namun, hingga saat ini pengembangan wisata kuliner dengan memanfaatkan hasil produksi pertanian, peternakan, dan perikanan masyarakat lokal belumlah optimal. Di Kintamani contohnya, di daerah ini merupakan penghasil ikan mujair terbanyak yang berasal dari danau justru menjual makananya dengan cara perasmanan dan menu yang disajikan bukanlah ikan mujair, melainkan makanan lainnya seperti cap cay, nasi goreng, mie goreng, dan masakan jenis chinesse food lainnya. Padahal, apabila ikan mujair tersebut diolah dan dikemas dengan baik serta menarik hingga menjadi sebuah oleholeh yang khas dari Kintamani, tentu akan memberikan keuntungan yang lebih khususnya bagi masyarakat. Hal ini belum dilakukan oleh masyarakat karena kurangnya pengetahuan serta kemampuan untuk mengolah bahan baku lokal tersebut menjadi produk wisata yang memiliki nilai jual yang tinggi.

Tersedianya hasil produksi masyarakat dalam bidang pertanian, peternakan, dan perikanan seharusnya dapat dilakukan beberapa kajian dalam memanfaatkan potensi yang dimiliki untuk dapat menghasilkan uang. Terlebih lagi, saat ini generasi muda cenderung enggan untuk bekerja di bidang-bidang ini dengan alasan kerja yang berat namun penghasilan yang tidak menentu. Akan tetapi, apabila hasil produksi ini dapat diolah untuk memenuhi kebutuhan pariwisata dan mampu menghasilkan uang, maka hal ini akan memberi pemikiran baru bagi generasi muda untuk bekerja lebih baik pada sektorsektor ini. Di Kabupaten Buleleng sesungguhnya ditemukan beberapa potensi yang dapat dikemas menjadi wisata kuliner sepert: Duren, Anggur, Pohon Aren, Kambing Etawa, Kopi Luwak dan sebagainya. Namun, tidak semua warga masyarakat, khususnya petani penghasil produk ini memahaminya.

Berdasarkan atas kenyataan tersebut, maka penelitian ini perlu dilakukan. 
Ada dua permasalahan pokok yang perlu ditemukan jawabannya. Pertama, hasil produksi pertanian apa saja yang memiliki potensi untuk dikembangkan menjadi produk wisata kuliner di Kabupaten Buleleng?. Kedua, produk wisata kuliner apa saja yang dapat dikembangkan dari hasil produksi pertanian masyarakat di Kabupaten Buleleng? Hasil penelitian ini diharapkan dapat meningkatkan pemahaman masyarakat, baik tentang potensi yang dimiliki, proses pengolahan bahan baku lokal menjadi produk wisata kuliner yang unik bercita rasa tinggi dan menarik bagi konsumen, khususnya wisatawan. Selanjutnya, diharapkan menginspirasi tumbuhnya ekonomi kreatif khususnya yang berkaitan dengan wisata kuliner di Kabupaten Buleleng.

Sebagai alat bantu untuk membedah fenomena yang dikaji digunakan gagasan atau pemikiran ahli yang relevan di antaranya Suwantoro (2004:48). Suwantoro menyatakan bahwa salah satu ciri produk wisata adalah tidak dapat dipindahkan, tetapi wisatawan-lah yang harus datang jika ingin menikmati produk wisata yang diproduksi, merupakan hal yang tepat untuk dijadikan dasar pengembangan wisata kuliner. Hal ini patut diterapkan, mengingat bahwa dalam pengembangan wisata kuliner dengan memanfaatkan bahan baku lokal, manfaat ekonomis harus dinikmati secara langung oleh masyarakat setempat. Dengan demikian, tentu tidak hanya produk wisata kulinernya saja yang diproduksi, namun masyarakatnya juga harus diberikan pembinaan dan pelatihan sehingga mampu menjadi pengolah, penyaji sekaligus sebagai penjual produk wisata kuliner tersebut.

John M. Echols (1993) menjelaskan bahwa Culinary dapat diartikan sebagai sesuatu yang berhubungan dengan dapur atau masakan. Sementara itu, Suparwoko (2010) dengan menggabungkan pemahamannya terhadap arti kuliner yang diperolehnya di internet (http:// en.wikipedia.org/wiki/ Culinaryprofesion) mendeskripsikan kuliner adalah dapur yang biasa digunakan untuk merujuk pada sesuatu yang berhubungan dengan memasak atau mempersiapkan makanan seperti chef, manajemen restoran, dan lainnya. Wisata kuliner dijelaskan olehnya sebagai suatu kegiatan perjalanan pariwisata yang dilakukan oleh wisatawan dengan tujuan untuk menikmati makanan dan minuman.

\section{METODE}

Pengumpulan data pada penelitian dilakukan dengan cara survei lapangan, wawancara mendalam, dan studi pustaka untuk mencari berbagai jenis hasil produksi yang dihasilkan oleh masyarakat di daerahdaerah di Bali. Adapun proses tahapan pengumpulan data yang dilakukan pada penelitian ini adalah (1) Identifikasi hasil produksi masyarakat, (2) Identifikasi resepresep, (3) Pengolahan hasil produksi sesuai resep, (4) Kuliner yang telah dihasilkan, (5) Uji coba pasar kepada konsumen, (6) Promosi wisata kuliner di Bali. Melalui pengumpulan data ini hasil yang diperoleh pada penelitian tahap I adalah resep-resep yang dapat diterapkan kepada masyarakat pada penelitian tahap berikutnya.

\section{HASIL PENELITIAN DAN PEMBAHASAN}

\section{Identifikasi Hasil Produksi Pertanian di Kabupaten Buleleng}

Kabupaten Buleleng merupakan wilayah Bali Utara yang masih dikenal sebagai wilayah yang belum berkembang, khususnya di bidang pariwisata. Hal ini disebabkan karena wilayah ini cukup jauh dari ibu kota provinsi Bali dan Bandara Udara Ngurah Rai yang merupakan pintu masuk utama wisatawan ke Bali. Kabupaten Buleleng terletak di belahan utara Pulau Bali. Secara geografis terletak pada posisi 8003'40"-8023"00" LS dan 114025"55" 115027'28" BT. Kabupaten Buleleng berbatasan langsung dengan Laut Jawa di bagian Utara, Kabupaten Karangasem di 
bagian Timur, Kabupaten Jembrana di bagian Barat dan Kabupaten Tabanan, Badung dan Kabupaten Bangli di bagian Selatan. Secara keseluruhan, luas wilayah Kabupaten Buleleng 1.365,88 km2 atau $136.588 \mathrm{Ha}$. Dari luas tersebut, $91,38 \%$ $(124.819 \mathrm{Ha})$ adalah lahan kering, 8,40\% (11.472 Ha) adalah lahan sawah dan 0,22\% (297 Ha).

Potensi komoditi pertanian dalam arti luas di Kabupaten Buleleng antara lain: tanaman pangan (padi sawah, palawija), hortikultura (anggur, mangga, rambutan, durian, jeruk, dll), perkebunan rakyat (kopi, cengkeh, vanili, pisang, dII), peternakan (sapi, kambing, ayam kampung, dll), perikanan laut dan perikanan darat/air payau (Antara dkk., 2002). Namun dari hasil observasi di wilayah Buleleng Timur, utamanya Kecamatan Tejakula, jenis tanaman pangan yang sedang diusahakan oleh petani setempat di antaranya yaitu: ketela rambat, ketela pohon dan jagung. Jenis tanaman tahunan atau perkebunan yaitu: kelapa, rontal, rambutan, mangga, kakao, mete, dan sawo.

Dijelaskan juga oleh Antara bahwa pengembangan pertanian lahan kering, utamanya di Kabupaten Buleleng dan Karangasem melalui pendekatan agribisnis adalah suatu langkah yang benar dan tepat (on the right track), karena: 1) Pendekatan ini mengintegrasikan secara vertikal dari aktivitas hulu ke hilir dan secara horizontal antara berbagai sektor, sehingga akan mampu menciptakan profit yang layak bagi petani di lahan kering; 2) Dalam usaha mewujudkan pengembangan pertanian lahan kering melalui pendekatan agribisnis yang berpotensi meningkatkan pendapatan petani sekaligus menghilangkan kesenjangan ekonomi, perlu dukungan keinginan politik (political will) dari pemerintah (pusat, propinsi dan kabupaten) dan masyarakat luas termasuk Lembaga Swadaya Masyarakat (LSM) di Kabupaten Buleleng. Mereka dapat menjadi aktor penting dalam mewujudkannya, baik melalui sosialisasi strategi pengembangan maupun melalui pendapingan petani dalam pengembangan agribisnis unggulan dan koperasi agribisnis (Antara, 2010).

Hasil produksi pertanian yang memiliki potensi besar untuk dikembangkan menjadi produk wisata kuliner di Kabupaten Buleleng dapat dipaparkan sebagai berikut.

\section{Durian}

Durian merupakan salah satu hasil produksi masyarakat Bali yang cukup memiliki potensi untuk dikembangkan sebagai wisata kuliner. Jumlah durian yang dihasilkan per tahunnya adalah 8.127 ton. Berdasarkan data BPS Provinsi Bali tahun 2011 daerah yang paling banyak menghasilkan buah durian adalah 1) Bangli sebanyak 2.573 ton, 2) Buleleng sebanyak 1860 ton dan 3) Gianyar sebanyak 1.549 ton. Masa panen buah durian berkisar antara bulan November - Februari. Namun, ada juga buah durian yang sengaja dibudidayakan agar tidak memiliki musim, dalam artian buah durian yang ditanam dapat dipanen kapan saja tanpa mengenal waktu.

Buah durian atau duren berkhasiat dan bermanfaat untuk kesehatan bagi tubuh manusia. Buah durian ternyata paling banyak mengandung karbohidrat, lemak, dan protein. Tak cuma itu, kandungannya masih ada zat-zat lain seperti serat, kalsium, asam folat, magnesium, zinc dan besi juga ada di dalamnya. Dalam 100 gram durian terkandung 147 Kkal. Artinya, ketika seseorang makan 1 (satu) kg durian, jumlah kalori yang ia dapatkan 1.470 Kkal atau sudah sebanding dengan porsi makannya selama satu hari. Buah durian juga banyak mengandung gula meski ada kandungan mangan yang bisa menjaga kadar gula agar tetap stabil. Biji durian belum diketahui manfaat maupun khasiatnya walapun biji durian dapat dimakan atau dikonsumsi, biasanya dibuat bubur durian.

Dijelaskan juga beberapa penyakit yang bisa diatasi dengan makan buah durian yang tidak terlalu banyak yakni: 1) Mengatasi sembelit karena banyak mengandung serat, 2) Mengatasi anemia 
karena mengandung folat atau Vitamin B9 yang dibutuhkan untuk memproduksi sel darah merah, 3) Menjaga kesehatan kulit karena mengandung Vitamin $\mathrm{C}$ yang berfungsi sebagai antioksidan dan antipenuaan, 4) Mengandung banyak potasium atau kalsium sehingga baik untuk keseahtan tulang dan persendian, 5) Mengkonsumsi dalam jumlah yang tidak berlebihan, kandungan mangaan dalam durian bisa menjaga kadar gula darah tetap stabil, 6) Mengandung senyawa tembaga yang bisa menjaga kesehatan kelenjar tiroid, 7) Menjaga nafsu makan karena banyak mengandung thiamin atau Vitamin $\mathrm{B} 1,8$ ) Mengatasi migrain karena mengandung senyawa riboflavin atau Vitamin B2, 9) Meredakan stres dan mengatasi depresi karena mengandung Vitamin B6 atau piridoksin, 10) Menjaga kesehatan gigi dan mulut karena mengandung phosphor.

Sebagai buah yang memiliki rasa yang gurih, buah durian ini dapat dikemas menjadi berbagai jenis makanan dan minuman yang lezat.

\section{Singkong/ Ubi Jalar/ Ubi Ungu}

Tanaman pangan dapat diklasifikasi ke dalam tiga kelompok, yakni: tanaman bahan makanan, sayur-sayuran, dan buah-buahan. Tanaman bahan makanan meliputi jenis padi-padian, jagung, umbi-umbian, dan kacang-kacangan. Hasil produksi ubi kayu/singkong di Bali mencapai 107.589 ton dengan penghasil terbesar adalah kabupaten Karangasem, yakni 61.056 ton pada tahun 2010. Untuk ubi ungu yang juga dikategorikan sebagai ubi jalar menghasilkan sebanyak 23.958 ton dengan penghasil terbanyak adalah kabupaten Bangli, yakni 9.891 ton (BPS Provinsi Bali, 2011). Kemudian, disusul oleh kabupatenkabupaten lainnya di Bali termasuk kabupaten Buleleng

\section{Anggur}

Buah anggur banyak ditemukan di kabupaten Buleleng, yakni di kecamatan Banjar dan kecataman Gerokgak. Buah anggur yang dihasilkan oleh masyarakat di kedua kecamatan ini cukup banyak. Pada tahun 2010 dihasilkan 11.111 ton buah angur yang dijual ke berbagai daerah yang ada di Bali. Masyarakat hingga saat ini telah menjual buah anggur dan mengolahnya untuk dikonsumsi langsung, diolah menjadi jus, wine dan kismis. Buah anggur yang dihasilkan dijual oleh petani kepada pengepul/tengkulak yang kemudian disalurkan lagi oleh pengecer kepada konsumen. Terkecuali, apabila buah anggur itu dibeli oleh perusahaan wine yang membeli dalam jumlah besar langsung membeli ke petani untuk diolah di pabriknya.

\section{Deskripsi Potensi Wisata Kuliner Berbahan Baku Lokal di Kabupaten Buleleng}

Berdasarkan hasil uji coba yang dilakukan pada penelitian ini, dihasilkan beberapa resep makanan yang potensial dikembangkan menjadi produk wisata kuliner. Adapun jenis-jenis resep makanan dimaksud dapat diuraikan sebagai berikut.

\section{Buah Durian}

Ada beberapa desa di kabupaten Buleleng yang menjadi sentra penghasil buah durian terkenal di Bali di antaranya desa Tajun, desa Munduk, desa Bestala, desa Sudaji, desa Silangjana, desa Sawan, dan desa Menyali. Beberapa jenis makanan yang dapat dikembangkan dari bahan baku buah durian adalah:

1) Kolak Duren Spesial dari Tanah Buleleng dibuat dengan menggunakan buah durian asli dari Kabupaten Buleleng, pisang yang dibuat menjadi kolak, gula aren buatan masyarakat Kabupaten Buleleng dan kuud ental yang merupakan buah dari pohon palem (ental).

2) Dodol Duren, melalui pemanfaatan duren lokal asli dihasilkan dodol duren dengan cita rasa yang lezat, namun tidak terlalu menyengat.

3) Jus Duren Spesial, merupakan jus dengan menggunakan buah duren kane 
yang dagingnya banyak dan rasanya yang khas.

4) Pudding Duren Kane, rasa durennya yang gurih dapat dirasakan pada pudding yang menggunakan duren lokal yang meruapakn buah asli dari Kabupaten Buleleng.

\section{Singkong/Ubi Jalar/Ubi Ungu}

Singkong/ ubi jalar/ ubi ungu dapat diolah menjadi tepung dan selanjutnya diolah menjadi berbagai kue yang enak dan lezat. Selain itu, singkong juga dapat langsung dikonsumsi tanpa dibuat tepung terlebih dahulu, namun memerlukan berbagai jenis pengolahan tradisional. Berdasarkan hasil penelitian ada Beberapa resep dengan menggunakan bahan baku singkong/ ubi jalar/ ubi ungu di antaranya:

1) Dodol Ubi Jalar, dibuat dengan menggunakan tepung ketan, tepung ubi jalar, gula pasir, dan santan. Rasanya yang kenyal dan enak dapat menjadi salah satu produk dodol baru yang dikembangkan di Kabupaten Buleleng.

2) Pound Cake Ubi Jalar Ungu, dengan mengolah ubi jalar ungu menjadi tepung sehingga dapat diolah menjadi berbagai jenis kue, salah satunya kue pound.

3) Opak kulit singkong, terbuat dari kulit singkong, tepung singkong (cassava) dan tepung tapioca. Rasanya yang gurih dan yang menonjol adalah pemanfaatan kulit singkong menajdi bahan makanan khas Buleleng.

4) Singkong rebus tuak, merupakan teknik merebus singkong dengan menggunakan nira pohon aren atau pohon lontar. Hal ini sering dilakukan oleh masyarakat penghasil gula aren atau gula lontar, yang pada saat pembuatan gula, singkong direbus di dalam nira tersebut, sehingga singkong terasa sangat manis dan kenyal.

\section{Buah Anggur}

Anggur paling mudah dibuat menjadi aneka minuman dan sebagai perasa dalam kue seperti pudding dan agar- agar. Kabupaten Buleleng sangat terkenal dengan anggur hitamnya yang rasanya akan terasa sangat manis apabila dikonsumsi setelah buah matang dengan sempurna dan dibiarkan beberapa waktu hingga tangkai yang memegang anggur agak kering. Buah anggur yang ada di kabupaten Buleleng tidak saja diolah menjadi berbagai jenis minuman yang bisa diminum secara langsung oleh konsumen, namun juga dapat dioleh menjadi wine. Bahkan, buah anggur asli Buleleng telah dikontrak oleh salah satu perusahaan wine yang ada di Bali, yakni Hatten Wine. Melihat potensi yang dimiliki oleh anggur yang di budidayakan oleh masyarakat lokal kabupaten Buleleleng di desa Banjar, Seririt, dan Gerokgak, maka haruslah mendapat perhatian khusus dari pihak pemerintah dan pengusaha pariwisata untuk dapat dikembangkan menjadi daerah wisata kuliner dengan produk unggulannya berupa buah anggur.

\section{PEMBAHASAN}

Hasil penelitian (identifikasi potensi dan hasil uji coba) menunjukkan bahwa di satu sisi Kabupaten Buleleng memiliki produk pertanian yang potensial dikembangkan menjadi produk wisata kuliner. Namun, di sisi lain dihadapkan pada persoalan lemahnya kemampuan (pengetahuan dan pengalaman) sumberdaya petani untuk mengolah produk pertaniannya menjadi produk wisata kuliner.

Selama ini para petani hanya menjual langsung maupun tidak langsung hasil pertaniannya kepada konsumen. Dengan cara seperti ini tentu keuntungan yang diraih tidak terlalu banyak, terlebih-lebih ketika produksi melimpah.

Oleh karena itu dalam rangka meningkatkan pendapatan para petani, maka pengembangan produk wisata kuliner berbahan baku lokal perlu dilakukan melalui pemberdayaan masyarakat lokal sebagai pengolah, penyaji, dan penjualnya perlu dilakukan.

Dengan demikian akan bertumbuh ekonomi kreatif, khususnya di bidang 
kuliner. Di samping itu diharapkan akan dapat meningkatkan kesejahteraan masyarakat, dan ini sejalan dengan dengan program Master Plan Percepatan Pembangunan Ekonomi Indonesia (lihat pula Wesnawa, 2011).

Di samping itu, pengembangan wisata kuliner adalah penting. Bukan semata karena bisa dikembangkan sebagai produk wisata alternatif, sehingga berkembang dipersifikasi produk wisata, akan tetapi juga peluang yang harus ditangkap (tuntutan pasar). Dikatakan demikian karena dalam kegiatan pariwisata ada unsur budaya, yakni makanan yang menjadi daya tarik wisatawan. Hal ini sejalan dengan pendapat Shaw dan Williams (dalam Ardika, 2003). Dinyatakan, bahwa dalam kegiatan pariwisata terdapat sepuluh elemen budaya yang menjadi daya tarik bagi wisatawan yakni: (1) kerajinan; (2) tradisi; (3) sejarah dan suatu tempat/daerah; (4) arsitektur; (5) makanan lokal/tradisional; (6) seni musik; (7) cara hidup suatu masyarakat; (8) agama; (9) bahasa; (10) pakaian lokal/tradisional.

\section{SIMPULAN}

Berdasarkan hasil penelitian dan pembahasan dapat disimpulkan bahwa teridentifikasi sejumlah komuditas pertanian yang memiliki potensi untuk dikembangkan menjadi produk Wisata kuliner di Kabupaten Buleleng. Sejumlah komuditas pertanian dimaksud di antaranya adalah buah durian, singkong/ubi jalar/ubi ungu, dan buah anggur.

Produk wisata kuliner yang dapat dikembangkan dari hasil produksi pertanian masyarakat di Kabupaten Buleleng, dapat dikelompokkan berdasarkan bahan bakunya, yakni buah durian, singkong/ubi jalar/ubi ungu. Dari bahan baku buah durian dihasilkan produk wisata kuliner seperti: Kolak Duren Spesial, Dodol Duren, Jus Duren Spesial, Pudding Duren Kane, rasa durennya yang gurih. Dari bahan baku singkong/ubi jalar/ubi ungu di hasilkan produk wisata kuliner berupa Dodol Ubi Jalar, Pound Cake Ubi Jalar Ungu, Opak kulit singkong, dan Singkong rebus tuak. Sementara, dari bahan baku buah anggur dihasilkan aneka minuman dan sebagai perasa dalam kue seperti pudding dan agaragar.

Mengingat potensi yang dimiliki, maka pengembangan produk wisata kuliner berbahan baku lokal perlu dilakukan melalui pemberdayaan masyarakat lokal sebagai pengolah, penyaji, dan penjualnya perlu dilakukan. Dengan demikian akan bertumbuh ekonomi kreatif, khususnya di bidang kuliner, sekaligus akan dapat meningkatkan kesejahteraan masyarakat, dan ini sejalan dengan program Master Plan Percepatan Pembangunan Ekonomi Indonesia.

\section{DAFTAR PUSTAKA}

Antara, Made. 2010 http://ejournal. unud.ac.id/abstrak/\%285\%29\%20socaantara-pendekatan\%20agribisnis \%281\%29.pdf,

Ariani, Risa Panti 1994, Studi Kelayakan Seni Kuliner Bali Mengenai Hidangan Tradisional Propinsi Bali, Laporan Penelitian, Lembaga Penelitian dan Pengabdian Kepada Masyarakat, STKIP Singaraja.

Ariani, Risa Panti 2011, Pengembangan Media Pembelajaran Berdasarkan Hasil-Hasil Penelitian Boga Sebagai Usaha Peningkatan Mutu Pangan, Lembaga Penelitian Universitas Pendidikan Ganesha, Singaraja.

Astra Wesnawa, I Gede, dkk, 2011, Pengembangan Potensi Pariwisata Berkelanjutan Bagi Peningkatan Kehidupan Sosial Ekonomi Masyarakat Pada Koridor Bali Sebagai Pintu Gerbang Pariwisata Nasional, Lembaga Penelitian Universitas Pendidikan Ganesha, Singaraja, Bali

Badan Pusat Statistik Provinsi Bali, 2011, Bali Dalam Angka, Denpasar 
Echols, John M. 1993, Analisa Pasar Ditinjau Dari Persepsi Wisatawan Terhadap Kuliner di Kabupaten Sleman

Suparwoko, 2010. Pengembangan Ekonomi Kreatif Sebagai Penggerak Industri
Pariwisata, Simposium Nasional 2010, Menu Purworejo Dinamis dan Kreatif, Universitas Islam Indonesia, Yogyakarta

Suwantoro, Gamal. 2004. Dasar-Dasar Pariwisata. Andi. Yogyakarta. 